\title{
Treatment of Dentin Hypersensitivity: A Systematic Review of Randomized Clinical Trials
}

\author{
Leye Benoist $\mathrm{F}^{*}$, Niang SO, Faye B, Sarr M, Seck A, Ndiaye D, Baldé O and Touré B \\ Department of Conservative Dentistry and Endodontics University Cheikh Anta Diop-Dakar, Senegal
}

${ }^{*}$ Corresponding author: Leye Benoist F, Department of Conservative Dentistry and Endodontics University Cheikh Anta Diop-Dakar, BP 16014 Dakar-Fann, Senegal, Tel: 00 221775247885, E-mail: fatou.leye@ucad.edu.sn

Citation: Leye Benoist F, Niang SO, Faye B, Sarr M, Seck A, et al. (2016) Treatment of Dentin Hypersensitivity: A Systematic Review of Randomized Clinical Trials . J Dent Oral Care Med 2(2): 204. doi: 10.15744/24543276.2.204

Received Date: January 25, 2016 Accepted Date: May 11, 2016 Published Date: May 13, 2016

\begin{abstract}
Aim: Dentin hypersensitivity (DH) is generally described as "a brief, sharp, and acute pain emanating from exposed dentin in response to thermal, tactile, osmotic, or chemical stimuli, as well as exposure to air that cannot be attributed to any dental anomaly or pathology". Several products have been assessed in regard to their effects on $\mathrm{DH}$, including home remedies containing strontium fluorides or chlorides, and more recently substances such as bioactive glass-ceramics and arginine. These products have generally been shown to be safe and beneficial for patients afflicted by DH. The aim of this work was to provide a systematic review of randomized clinical trials (RCT) of the various therapeutic solutions for DH that have been described in the literature from the $1^{\text {st }}$ of January 2009 to the $30^{\text {th }}$ of September 2015.

Materials and Methods: Several electronic databases such as Cochrane Oral Health Group Trials Register, the Cochrane Central Register of Controlled Trials (CENTRAL), Medline and Embase were accessed. In addition, some studies were identified by hand searching.

Results: The electronic and manual search strategies with which we examined the target databases returned 301 articles that were then listed in a QUOROM flow diagram to demonstrate the selection process for the written materials that were retained for a final analysis. Only 17 articles were finally selected.

Conclusion: Comparisons between the various therapeutic options did not reveal any significant short-term differences, although the laser-based treatments proved to be much more effective in the long run. The same can be said for cyanoacrylate, which was found to be as effective as low-intensity laser treatment for reducing dentin hypersensitivity. Further, it is a more readily accessible and less costly procedure that is entirely safe for use in treating dentin hypersensitivity.

Keywords: Systematic review; Dentin hypersensitivity; Clinical trial

List of abbreviations: DH: Dentin hypersensitivity; RCT: Randomized Clinical Trial; CONSORT: Consolidated Standards of Reporting Trials
\end{abstract}

\section{Introduction}

Dentin hypersensitivity (DH) is generally described as "a brief, sharp, and acute pain emanating from exposed dentin in response to thermal, tactile, osmotic, or chemical stimuli, as well as exposure to air that cannot be attributed to any dental anomaly or pathology" [1-3].

Depending on the study, the reported prevalence of DH ranges from 3 to $57 \%$, and it is estimated to affect $15 \%$ of the adult population, on average [2,3]. Although its occurrence increases with age, the majority of afflicted individuals are between 20 and 50 years of age, with a peak between 30 and 40 years of age [2,3]. Women are affected more than men [2,3]. Patients who exhibit periodontal diseases tend to be afflicted more often, with a prevalence that varies between 72 and $98 \%$ [2,3].

Several products have been assessed in regard to their effects on $\mathrm{DH}$, including home remedies containing strontium fluorides or chlorides, and more recently substances such as bioactive glass-ceramics and arginine [4]. These products have generally been shown to be safe and beneficial for patients afflicted by DH [4]. The scientific data underlying the treatments are also varied, such that deciding on a suitable treatment can present a dilemma for the treating physician. The best way to undertake a thorough, all encompassing, and in-depth assessment of the medical literature is to provide an objective summary through a systematic review that allows the best possible scientific proof to come to light. Systematic reviews regarding therapeutic strategies for DH have been published [4]. In light of the emergence of new therapeutic approaches such as lasers and arginine, there is now however ample scope for a new systematic review of this subject. 
The aim of this work was to provide a systematic review of randomized clinical trials (RCT) of the various therapeutic solutions for $\mathrm{DH}$ that have been described in the literature from the $1^{\text {st }}$ of January 2009 to the $30^{\text {th }}$ of September 2015.

\section{Materials and Methods}

\section{The issue in question}

The pain decreases or disappears after a curative treatment of the DH?

\section{Criteria for considering studies for this review}

Types of studies: randomized clinical trials for which the duration of the intervention was 4 weeks or more.

Types of participants: individuals of all ages, irrespective of gender.

Types of interventions

Active interventions: desensitizing products, lasers

Control: placebo

Types of outcome measures: decrease or suppression of the $\mathrm{DH}$.

The strategy for finding documents was comprised of two stages. We firstly undertook an electronic search of scientific publication databases, such as Medline and Cochrane Library. This was followed by a manual search of the references in the publications identified by the electronic database search, as well as via the main odontology journal websites. These searches spanned the period from the $1^{\text {st }}$ of January 2009 to the $30^{\text {th }}$ of September 2015. The MeSH headings that we used were (Dentin sensitivities) AND ("Prevention and control" OR "Radiotherapy" OR "Rehabilitation" OR “Therapy"). The search was restricted to randomized clinical trial results. No restriction was placed on the language of the materials.

\section{Selection strategy for the studies}

The publications derived from the electronic database search that was based on the various parameters, and from the manual search, were subject to review based on assessment of the titles and the abstracts. Two review authors then independently carried out a selection of the studies to be included in this systematic review. The publications that did not provide sufficient relevant information as judged by this first screening were discarded at this stage. Full copies of the publications for which the titles and abstracts were not sufficiently informative to clearly warrant their inclusion were examined further. Two procedures were used for this: one based on use of HINARI software and the other based on the resources of the InterUniversity Medical Library of Paris.

Following completion of this independent selection approach, the two sets of results were compared. Any incompatibilities in this regard were discussed and resolved through consultation with a third author for this review article.

\section{Analysis of the quality of the studies}

Assessment of the quality of the methodologies for all of the included studies was done in an independent manner in keeping with guidelines of the revised CONSORT (Consolidated Standards of Reporting Trials) statement by two blinded conservative odontology specialists (Table 1) [5]. Once the scores had been determined, an overall risk of bias (low, moderate, or high) was assigned for each study that had been selected. The risk was deemed to be low when all of the criteria were fulfilled, moderate when one or more criteria were at least partially fulfilled, and high when one or more criteria were not taken into account.

\begin{tabular}{|c|l|l|}
\hline Category & \multicolumn{1}{|c|}{ Description } & \multicolumn{1}{c|}{ Grading } \\
\hline \multirow{2}{*}{ A } & $\begin{array}{l}\text { Sample size calculation, estimating the minimum } \\
\text { number of participants required to detect a } \\
\text { significant difference among compared groups }\end{array}$ & $\begin{array}{l}0=\text { did not exist/not mentioned/ not clear } \\
1=\text { reported but not confirmed } \\
2=\text { reported and confirmed }\end{array}$ \\
\hline \multirow{2}{*}{ B } & $\begin{array}{l}\text { Randomization and allocation concealment } \\
\text { methods }\end{array}$ & $\begin{array}{l}0=\text { clearly inadequate } \\
1=\text { possibly adequate } \\
2=\text { clearly adequate }\end{array}$ \\
\hline \multirow{2}{*}{ C } & $\begin{array}{l}\text { Clear definition of inclusion and/or exclusion } \\
\text { criteria }\end{array}$ & $\begin{array}{l}0=\text { no } \\
1=\text { yes }\end{array}$ \\
\hline \multirow{2}{*}{ D } & $\begin{array}{l}\text { Completeness of follow-up (specified reasons for } \\
\text { withdrawals and dropouts in each study group) }\end{array}$ & $\begin{array}{l}0=\text { no/not mentioned/not clear } \\
1=\text { yes/no withdrawals or dropouts occurred }\end{array}$ \\
\hline \multirow{2}{*}{ E } & Experimental and control groups comparable at & $\begin{array}{l}0=\text { no } \\
1=\text { unclear/possibly not comparable for one or } \\
\text { more important prognostic factors } \\
2=\text { clearly adequate }\end{array}$ \\
\hline
\end{tabular}




\begin{tabular}{|c|l|l|}
\hline Category & \multicolumn{1}{|c|}{ Description } & \multicolumn{1}{c|}{ Grading } \\
\hline F & Presence of masking & $\begin{array}{l}0=\text { no } \\
1=\text { unclear/not complete } \\
2=y e s\end{array}$ \\
\hline \multirow{2}{*}{ G } & Appropriate statistical analysis & $\begin{array}{l}0=\text { no } \\
1=\text { unclear/not complete } \\
2=y e s\end{array}$ \\
\hline
\end{tabular}

Table 1: Categories for Assessing the Quality of Selected Studies

\section{Extraction of the data}

The data were entered in an independent manner into an Excel $^{\oplus}$ spreadsheet by a conservative odontology specialist. The parameters collected for each study were: the author(s), year of publication, country, type of study, study population (e.g. age and gender), number of subjects, type of intervention (e.g. RCT comparing two treatments, or a single treatment and a placebo), duration of the follow-up, and the outcomes.

\section{Results}

The electronic and manual search strategies with which we examined the target databases returned 301 articles that were then listed in a QUOROM flow diagram to demonstrate the selection process for the written materials that were retained for a final analysis (Figure 1).
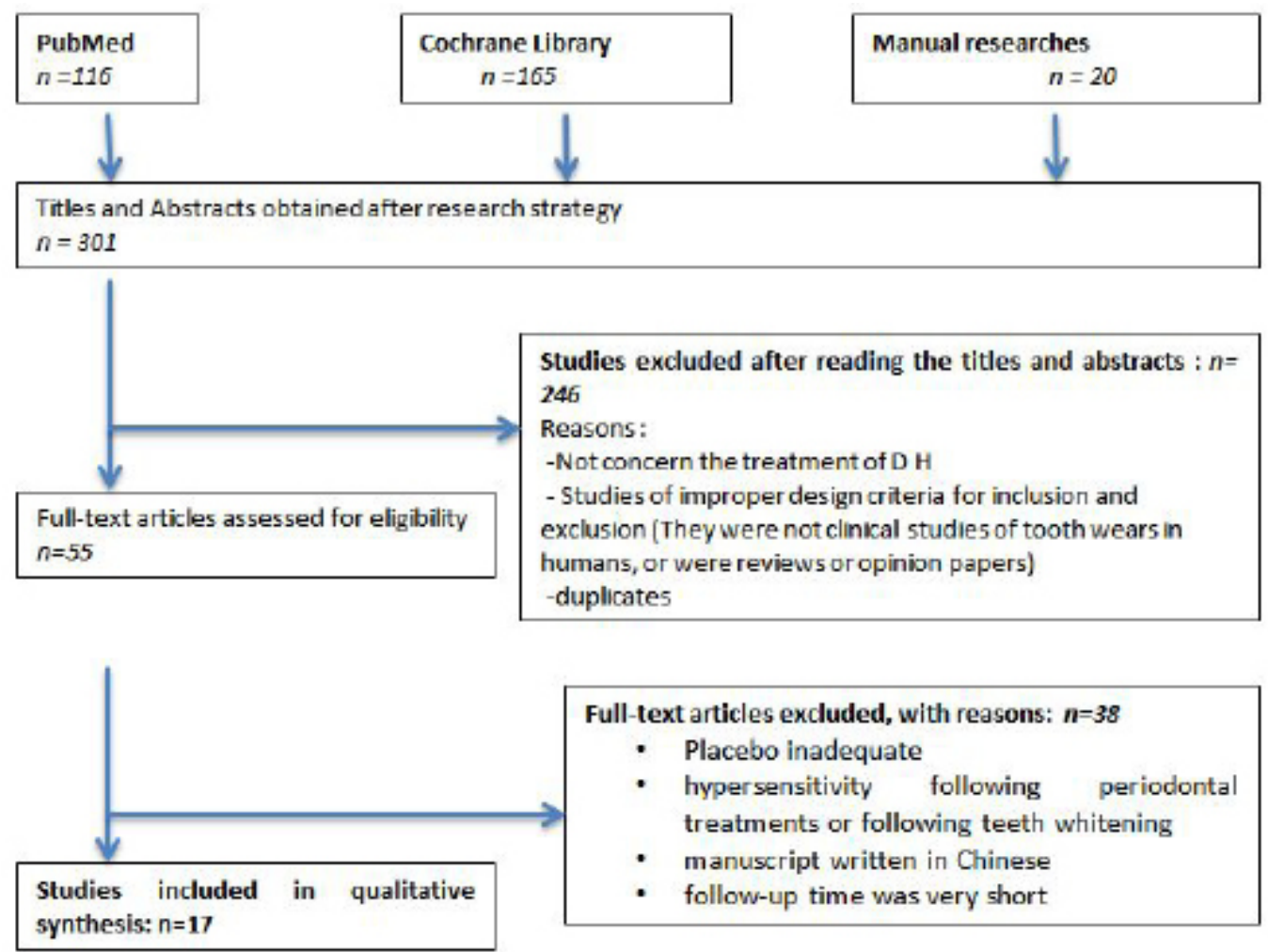

Figure 1: PRISMA flowchart of the search strategy

\section{Selection of the articles}

Perusal of the titles and the summaries of the selected articles by the two "reviewers" assigned to this task allowed 246 of these items to be eliminated for the following reasons:

- They did not really concern treatment of $\mathrm{DH}$;

- The study designs were of an in vivo nature, in situ with animals, and descriptive;

- Duplications of the same articles found both by PubMed and Cochrane searches.

Fifty-five articles were retained for a more in-depth analysis based on a more complete reading of the copies or reprints of the articles. Upon completion of this stage, a further 38 articles were excluded from our selection. These were essentially RCTs for which the chosen placebo was inadequate, or RCTs regarding hypersensitivity following periodontal treatments or following teeth whitening, a manuscript written in Chinese for which the translation did allow for proper assessment, and lastly also a study for which the follow-up time was very short and hence four weeks less than what was specified by our selection criteria. 
The remaining 17 articles were suitable for assessment of their quality and for extraction of the data.

\section{Assessment of the quality of the articles}

The results of the assessment of the quality of the articles are shown in Table 2.

\begin{tabular}{|c|c|c|c|c|c|c|c|c|c|}
\hline $\mathbf{N}^{\circ}$ & Autors & $A(0-2)$ & B (0-2) & $\mathrm{C}(0-1)$ & $\mathrm{D}(0-1)$ & $\mathrm{E}(0-2)$ & $F(0-2)$ & G (0-2) & $\begin{array}{l}\text { Risk of } \\
\text { b.ias }\end{array}$ \\
\hline 1 & Elias Boneta AR, et al. 2013 & 2 & 2 & 1 & 1 & 2 & 2 & 2 & Low \\
\hline 2 & Yilmaz HG, et al. 2011 & 2 & 1 & 1 & 1 & 2 & 1 & 2 & Low \\
\hline 3 & Azarpazhooh A, et al. 2009 & 2 & 2 & 1 & 1 & 2 & 2 & 2 & Low \\
\hline 4 & Brahmbhatt N, et al. 2012 & 2 & 2 & 1 & 1 & 2 & 2 & 2 & Low \\
\hline 5 & Flecha OD, et al. 2013 & 2 & 2 & 1 & 1 & 2 & 2 & 2 & Low \\
\hline 6 & Neuhaus KW, et al. 2013 & 2 & 2 & 1 & 1 & 2 & 2 & 2 & Low \\
\hline 7 & Orsini G, et al. 2010 & 2 & 2 & 1 & 1 & 2 & 2 & 2 & Low \\
\hline 8 & Aranha AC, et al. 2012 & 0 & 1 & 1 & 0 & 2 & 0 & 2 & High \\
\hline 9 & Kara C, et al. 2009 & 1 & 0 & 0 & 1 & 2 & 2 & 2 & High \\
\hline 10 & $\begin{array}{c}\text { Yilmaz HG, et al. } 2011 \\
\text { Turkey }\end{array}$ & 2 & 1 & 1 & 0 & 2 & 1 & 2 & High \\
\hline 11 & Assis JS, et al. 2011 & 2 & 2 & 1 & 1 & 1 & 1 & 2 & Moderate \\
\hline 12 & Hu D, et al. 2012 & 2 & 2 & 1 & 1 & 2 & 2 & 2 & Low \\
\hline 13 & He Tao, et al. 2014 & 2 & 2 & 1 & 1 & 2 & 2 & 2 & Low \\
\hline 14 & Ding YJ, et al. 2014 & 0 & 1 & 1 & 0 & 0 & 2 & 2 & High \\
\hline 15 & França IL, et al. 2015 & 0 & 2 & 1 & 0 & 2 & 1 & 2 & High \\
\hline 16 & Antoniazzi RP, et al. 2014 & 2 & 2 & 1 & 1 & 2 & 2 & 2 & Low \\
\hline 17 & Ko Y, et al. 2014 & 0 & 2 & 1 & 1 & 2 & 2 & 2 & Moderate \\
\hline
\end{tabular}

Table 2: Assessment of the quality of the articles

\section{The standard of proof}

Analysis of the quality based on CONSORT criteria showed that 10 articles were deemed to have a low risk of bias [6-15]. Two studies $[16,17]$ were considered to have moderate risks for bias. The criteria that were only partially fulfilled were the criteria for inclusion and exclusion, and the extent of the follow-up.

Five studies were seen as having an elevated risk of bias [18-22]. The first item that was most often unsatisfactory was the inadequate calculation of the sample size (Category A) $[18,19]$. The second item was the lack of information regarding the randomization (Category B) (Table 1) [18].

\section{Extraction of the data}

The key information contained in the 17 articles that were retained was extracted and compiled in Table 3.

\begin{tabular}{|c|c|c|c|c|c|c|}
\hline Number & $\begin{array}{l}\text { Author, Year, } \\
\text { Country }\end{array}$ & $\begin{array}{l}\text { Type of } \\
\text { study }\end{array}$ & Number of subjects & Aim & $\begin{array}{l}\text { Follow- } \\
\text { up time }\end{array}$ & Results \\
\hline 1 & $\begin{array}{l}\text { Elias Boneta } \\
\text { AR, et al. 2013, } \\
\text { Dominican } \\
\text { Republic }\end{array}$ & $\begin{array}{l}\text { Randomized, } \\
\text { double blind } \\
\text { clinical trial }\end{array}$ & $\mathrm{N}=120$ subjects & $\begin{array}{l}\text { Evaluate the efficacy of } \\
\text { three regimens integrating } \\
\text { toothpaste, toothbrush and } \\
\text { mouthwash in reducing } \\
\text { DH. }\end{array}$ & $\begin{array}{l}\text { Two, } \\
\text { four, and } \\
\text { eight } \\
\text { weeks }\end{array}$ & $\begin{array}{l}\text { Arginine regimen provided the greatest } \\
\text { reduction in Tactile and Air-Blast DH } \\
\text { compared to potassium and negative control } \\
\text { regimens; and provides faster DH relief than } \\
\text { potassium regimen. }\end{array}$ \\
\hline 2 & $\begin{array}{l}\text { Yilmaz HG, } \\
\text { et al. } 2011 \text {, } \\
\text { Turkey }\end{array}$ & $\begin{array}{l}\text { Randomized } \\
\text { clinical trial }\end{array}$ & $\begin{array}{l}\mathrm{N}=48 \text { patients with } \\
244 \text { teeth affected } \\
\text { by } \mathrm{DH} \\
\text { G1: GaAlAs laser } \\
\text { G2: placebo laser } \\
\text { G3: NaF varnish G4: } \\
\text { placebo NaF varnish }\end{array}$ & $\begin{array}{l}\text { To evaluate and compare } \\
\text { the desensitizing effects } \\
\text { of a gallium aluminum } \\
\text { arsenide ( } \mathrm{GaAlAs}) \text { laser } \\
\text { and sodium fluoride }(\mathrm{NaF}) \\
\text { varnish on } \mathrm{DH}\end{array}$ & $\begin{array}{l}1,3 \\
\text { and } 6 \\
\text { months }\end{array}$ & $\begin{array}{l}\text { GaAlAs laser and NaF varnish treatments } \\
\text { resulted in a significant reduction in the } \\
\text { VAS scores immediately after treatments } \\
\text { that were maintained throughout the study } \\
\text { when compared to the baseline and placebo } \\
\text { treatments. }\end{array}$ \\
\hline 3 & $\begin{array}{l}\text { Azarpazhooh } \\
\text { A, et al.2009, } \\
\text { Germany }\end{array}$ & $\begin{array}{l}\text { Randomized, } \\
\text { triple blind } \\
\text { clinical trial }\end{array}$ & $\mathrm{N}=44$ patients & $\begin{array}{l}\text { to evaluate the effect of an } \\
\text { ozone delivery system } \\
\text { (HealOzone; KaVo, Biber- } \\
\text { ach, Germany) in reducing } \\
\text { DH. }\end{array}$ & 8 weeks & $\begin{array}{l}\text { All subjects reported a clinically significant } \\
\text { reduction of pain at each follow-up relative to } \\
\text { baseline; however, the difference between the } \\
\text { study groups was not statistically significant. } \\
\text { The effect of treatment of hypersensitive teeth } \\
\text { with ozone reduces the pain sensation, but } \\
\text { this effect cannot be distinguished from the } \\
\text { placebo treatment. }\end{array}$ \\
\hline
\end{tabular}




\begin{tabular}{|c|c|c|c|c|c|c|}
\hline Number & $\begin{array}{c}\text { Author, } \\
\text { Year, Coun- } \\
\text { try }\end{array}$ & $\begin{array}{l}\text { Type of } \\
\text { study }\end{array}$ & Number of subjects & Aim & $\begin{array}{c}\text { Follow-up } \\
\text { time }\end{array}$ & Results \\
\hline 4 & $\begin{array}{l}\text { Brahmbhatt } \\
\text { N, et al. } \\
\text { 2012, USA }\end{array}$ & $\begin{array}{l}\text { Randomized, } \\
\text { double blind } \\
\text { clinical trial }\end{array}$ & $\begin{array}{l}\mathrm{N}=25 \text { patients with } \\
260 \text { theeth } \\
2 \% \text { NaF solution } \\
\text { (group A), HEMA- } \\
\text { G(group B), placebo } \\
\text { (group C) and } \\
\text { NaF-iontophoresis } \\
\text { (Group D) }\end{array}$ & $\begin{array}{l}\text { To compare three dentin } \\
\text { desensitizing treatment } \\
\text { modalities. }\end{array}$ & $\begin{array}{l}\mathrm{J} 0, \mathrm{~J} 15, \\
1 \text { et } 3 \\
\text { months }\end{array}$ & $\begin{array}{l}\text { All treatments were effective in reducing DH } \\
\text { significantly; Group D and Group B were } \\
\text { more effective than Group A and Group C } \\
\text { at all time intervals. Group D and Group B } \\
\text { were equally effective in reducing DH at 15- } \\
\text { day and 1-month interval but Group D was } \\
\text { more effective at 3-months. }\end{array}$ \\
\hline 5 & $\begin{array}{l}\text { Flecha OD, } \\
\text { et al. } 2013 \text {, } \\
\text { Brazil }\end{array}$ & $\begin{array}{l}\text { Randomized, } \\
\text { double blind } \\
\text { clinical trial }\end{array}$ & $\begin{array}{l}434 \text { sensitive teeth } \\
\text { from } 62 \text { patients } \\
216 \text { teeth were treat- } \\
\text { ed with laser and } 218 \\
\text { with cyanoacrylate }\end{array}$ & $\begin{array}{l}\text { To evaluate the effective- } \\
\text { ness of cyanoacrylate in } \\
\text { the treatment of DH when } \\
\text { compared to the applica- } \\
\text { tion of low-intensity laser. }\end{array}$ & 6 months & $\begin{array}{l}\text { Both groups had significant reductions } \\
\text { in DH. However, there was no significant } \\
\text { difference between the two groups } \leq 6 \\
\text { months. Intragroup analysis showed that } \\
\text { the effect of cyanoacrylate obtained at } 24 \\
\text { hours remained for } 90 \text { days in response to } \\
\text { air-jet test and } 30 \text { days for cold-spray test. } \\
\text { There was a statistically significant difference } \\
\text { between all other intragroup comparisons at } \\
\text { the time. }\end{array}$ \\
\hline 6 & $\begin{array}{l}\text { Neuhaus } \\
\text { KW, et al. } \\
\text { 2013, Swit- } \\
\text { zerland }\end{array}$ & $\begin{array}{l}\text { Randomized, } \\
\text { double blind } \\
\text { clinical trial }\end{array}$ & $\begin{array}{l}\mathrm{N}=151 \text { subjects } \\
\mathrm{G} 1: 51 \text { NovaMin } \\
\text { and } \mathrm{NaF} \\
\mathrm{G} 2: 50 \text { NovaMin } \\
\mathrm{G} 3: 50 \text { placebo }\end{array}$ & $\begin{array}{l}\text { To determine the effective- } \\
\text { ness of a prophylaxis paste } \\
\text { containing } 15 \% \text { calcium } \\
\text { sodium phosphosilicate } \\
\left(\text { CSPS; NovaMin }\left(^{\circ}\right) \text { ) with }\right. \\
\text { and without fluoride in } \\
\text { reducing DH }\end{array}$ & 28 days & $\begin{array}{l}\text { Subjects having received the test prophy- } \\
\text { laxis pastes showed statistically lower DH } \\
\text { compared with the control group imme- } \\
\text { diately after the prophylaxis procedure. In } \\
\text { conclusion, the single application of both } \\
\text { fluoridated and non-fluoridated prophylaxis } \\
\text { pastes containing } 15 \% \text { CSPS (NovaMin }\left(^{\circ}\right) \text { ) } \\
\text { provided a significant reduction of DH up to } \\
\text { at least } 28 \text { days. }\end{array}$ \\
\hline 7 & $\begin{array}{l}\text { Orsini G, } \\
\text { et al. } 2010 \text {, } \\
\text { Italy }\end{array}$ & $\begin{array}{l}\text { Randomized, } \\
\text { double blind } \\
\text { clinical trial }\end{array}$ & $\begin{array}{l}\mathrm{N}=70 \text { subjects } \\
36 \text { received } \\
\text { the new dentifrice } \\
\text { and } 34 \text { the control }\end{array}$ & $\begin{array}{l}\text { To evaluate the desensi- } \\
\text { tizing efficacy of a new } \\
\text { dentifrice based on zinc- } \\
\text { carbonate hydroxyapatite } \\
\text { (CHA) nanocrystals }\end{array}$ & $\begin{array}{l}4 \text { and } 8 \\
\text { weeks }\end{array}$ & $\begin{array}{l}\text { As compared with controls, experimental } \\
\text { subjects had a significantly greater improve- } \\
\text { ment in the airblast test score and the subjec- } \\
\text { tive test score, with both differences already } \\
\text { being significant after } 4 \text { weeks. In contrast, } \\
\text { there was no significant difference between } \\
\text { groups for either the tactile or cold water } \\
\text { tests at any time point and with any outcome }\end{array}$ \\
\hline 8 & $\begin{array}{l}\text { Aranha AC, } \\
\text { et al. 2012, } \\
\text { Brazil }\end{array}$ & $\begin{array}{l}\text { Randomized, } \\
\text { double blind } \\
\text { clinical trial }\end{array}$ & $\begin{array}{l}\text { N = } 48 \text { patients } \\
\text { G1:7 Er:YAG } \\
\text { G2:7 Er,Cr:YSGG } \\
\text { G3:7 Er,Cr:YSGG } \\
\text { G4:7 Placebo }\end{array}$ & $\begin{array}{l}\text { To evaluate the effects of } \\
\text { Er:YAG and Er,Cr:YSGG } \\
\text { lasers on DH. }\end{array}$ & $\begin{array}{l}\text { Immedi- } \\
\text { ately after } \\
\text { treatment, } \\
\text { and } 1 \\
\text { week and } \\
1 \text { month } \\
\text { after treat- } \\
\text { ment }\end{array}$ & $\begin{array}{l}\text { Irradiation with the Er:YAG laser was associ- } \\
\text { ated with the lowest level of pain. With the } \\
\text { mechanical stimulus, group } 4 \text { showed the } \\
\text { most pronounced decrease in pain immedi- } \\
\text { ately after treatment; however, by the end of } \\
\text { the study, pain levels had increased. Groups } \\
1,2 \text { and } 3 \text { showed a reduction in pain that } \\
\text { was significantly different from that in group } \\
4 \text { after the } 4 \text { weeks of clinical follow up. }\end{array}$ \\
\hline 9 & $\begin{array}{l}\text { Kara C, et } \\
\text { al. 2009, } \\
\text { Turkey }\end{array}$ & $\begin{array}{l}\text { Randomized, } \\
\text { double blind } \\
\text { clinical trial }\end{array}$ & $\begin{array}{l}\mathrm{N}=20 \text { patients } \\
\mathrm{G} 1: 10 \text { Florides } \\
\mathrm{G} 2: 10 \text { Laser }\end{array}$ & $\begin{array}{l}\text { To evaluate and compare } \\
\text { the desensitizing effects } \\
\text { of the neodymium-doped } \\
\text { yttrium aluminium garnet } \\
\text { (Nd:YAG) laser and fluo- } \\
\text { ride varnish by considering } \\
\text { the degree of pre- and post } \\
\text { treatment pain, discomfort, } \\
\text { and functional complica- } \\
\text { tions }\end{array}$ & $\begin{array}{l}0,1,2 \\
3 \text { and } 4 \\
\text { weeks }\end{array}$ & $\begin{array}{l}\text { Laser treatment resulted in significant } \\
\text { improvements of discomfort immediately } \\
\text { after treatment and after } 1 \text { week. At the } 2,3 \text {, } \\
\text { and } 4 \text { week examination, the discomfort in } \\
\text { group fluoride decreased up to nearly } 75 \% \\
\text { to } 85 \% \text { of baseline scores, whereas the effect } \\
\text { of the laser stayed nearly unchanged. The } \\
\text { visual analog scale scores for pain at } 4 \text { weeks } \\
\text { examination were significantly lower in the } \\
\text { fluoride group compared with those in the } \\
\text { laser group. }\end{array}$ \\
\hline 10 & $\begin{array}{l}\text { Yilmaz HG, } \\
\text { et al. 2011, } \\
\text { Turkey }\end{array}$ & $\begin{array}{l}\text { Randomized, } \\
\text { double blind } \\
\text { clinical trial }\end{array}$ & $\begin{array}{l}\mathrm{N}=51 \text { patients } \\
\text { participated in this } \\
\text { study for a total of } \\
174 \text { teeth. } \\
\text { G1: erbium, chromi- } \\
\text { um doped:yttrium, } \\
\text { scandium, gal- } \\
\text { lium and garnet } \\
\text { (Er,Cr:YSGG) } \\
\text { G2: galium-alu- } \\
\text { minium-arsenide } \\
\text { (GaAlAs) laser }\end{array}$ & $\begin{array}{l}\text { To evaluate and compare } \\
\text { the desensitizing effects of } \\
\text { erbium, chromium } \\
\text { doped:yttrium, scan- } \\
\text { dium, gallium and garnet } \\
\text { (Er,Cr:YSGG) to } \\
\text { galium-aluminium-arse- } \\
\text { nide (GaAlAs) laser on DH }\end{array}$ & 4 weeks & $\begin{array}{l}\text { When compared with the control group and } \\
\text { baseline data, in both laser groups, laser } \\
\text { irradiation provided a desensitizing effect } \\
\text { immediately after treatment and this effect } \\
\text { was maintained throughout the study. No } \\
\text { significant differences between Er,Cr:YSGG } \\
\text { and GaAlAs laser groups were found at any } \\
\text { follow-up examination. }\end{array}$ \\
\hline
\end{tabular}




\begin{tabular}{|c|c|c|c|c|c|c|}
\hline Number & $\begin{array}{l}\text { Author, Year, } \\
\text { Country }\end{array}$ & $\begin{array}{l}\text { Type of } \\
\text { study }\end{array}$ & Number of subjects & Aim & $\begin{array}{l}\text { Follow- } \\
\text { up time }\end{array}$ & Results \\
\hline 11 & $\begin{array}{l}\text { Assis JS, et al. } \\
2011, \\
\text { Brazil }\end{array}$ & $\begin{array}{l}\text { Randomized, } \\
\text { double blind } \\
\text { clinical trial }\end{array}$ & $\begin{array}{l}\mathrm{N}=77 \text { teeth from } 13 \\
\text { patients } \\
\text { Oxa-Gel (G1), Sensi } \\
\text { Kill (G2) and placebo } \\
\text { gel (G3 - control) }\end{array}$ & $\begin{array}{l}\text { To evaluate the efficacy of } \\
\text { two desensitizing agents } \\
\text { (Oxa-Gel and Sensi Kill) in } \\
\text { the reduction of DH }\end{array}$ & $\begin{array}{l}1,2,3 \text { et } \\
4 \text { weeks }\end{array}$ & $\begin{array}{l}\text { The sensitivity scores were significantly } \\
\text { lower only for Sensi Kill in comparison to } \\
\text { the other products (Oxa-Gel and placebo), } \\
\text { when air stimulus was applied. It may be } \\
\text { concluded that treatment with Sensi Kill } \\
\text { presented a slightly better performance in } \\
\text { reducing DH when compared to the other } \\
\text { desensitizing agent. }\end{array}$ \\
\hline 12 & $\begin{array}{l}\text { Hu D, et al. } \\
2013 \text {, } \\
\text { China }\end{array}$ & $\begin{array}{l}\text { Randomized, } \\
\text { double blind } \\
\text { clinical trial }\end{array}$ & $\begin{array}{l}\mathrm{N}: 90 \text { subjects } \\
\text { G1 }: 45 \text { Arginine } \\
\text { G } 2: 45 \text { placebo }\end{array}$ & $\begin{array}{l}\text { To evaluate the DH reduc- } \\
\text { tion efficacy of a mouth- } \\
\text { wash using Pro-Argin }^{\text {no }} \\
\text { Mouthwash }\end{array}$ & 8 weeks & $\begin{array}{l}\text { After two weeks, four weeks and eight } \\
\text { weeks of product use, subjects in the } \\
\text { Arginine. Mouthwash group exhibited } \\
\text { statistically significant improvements in } \\
\text { mean tactile and air blast hypersensitivity } \\
\text { scores as compared to the Negative Control } \\
\text { Mouthwash. }\end{array}$ \\
\hline 13 & $\begin{array}{l}\text { He Tao, et al. } \\
\text { 2014, USA }\end{array}$ & $\begin{array}{l}\text { Randomized, } \\
\text { double blind } \\
\text { clinical trial }\end{array}$ & $\begin{array}{l}\mathrm{N}: 100 \text { patients } \\
\text { G1: }\left(\mathrm{SnF}_{2}\right) \text { dentifrice } \\
\text { G2: }(\mathrm{NaF}) \text { triclosan } \\
\text { dentifrice }\end{array}$ & $\begin{array}{l}\text { To evaluate the efficacy of } \\
\text { a marketed stabilized stan- } \\
\text { nous fluoride } \\
\left(\mathrm{SnF}_{2}\right) \text { dentifrice in reduc- } \\
\text { ing DH as compared to a } \\
\text { marketed sodium fluoride } \\
(\mathrm{NaF}) / \text { triclosan dentifrice. }\end{array}$ & $\begin{array}{l}8 \text {-week } \\
\text { period }\end{array}$ & $\begin{array}{l}\text { Twice-daily brushing with a marketed } \\
\mathrm{SnF}_{2} \text { dentifrice provided superior dentinal } \\
\text { hypersensitivity improvement versus a com- } \\
\text { mercially available NaF/triclosan dentifrice, } \\
\text { with significantly greater relief after two } \\
\text { weeks, and even larger relative benefits at } \\
\text { eight weeks. }\end{array}$ \\
\hline 14 & $\begin{array}{l}\text { Ding YJ, et al. } \\
\text { 2014, China }\end{array}$ & $\begin{array}{l}\text { Randomized, } \\
\text { double blind } \\
\text { clinical trial }\end{array}$ & $\begin{array}{l}\mathrm{N}=119 \text { teeth } \\
\mathrm{G} 1: \text { VTX } \\
\mathrm{G} 2: \text { GLUMA } \\
\text { G3 :Placebo (warm } \\
\text { water) }\end{array}$ & $\begin{array}{l}\text { To evaluate the effect of } \\
\text { Clinpro XT Varnish (VXT) } \\
\text { paste-liquid, } \\
\text { resin-modified glass- } \\
\text { ionomer and the resinous } \\
\text { dentin desensitizing } \\
\text { varnish and Gluma Dentin } \\
\text { Desensitizer (Gluma) in } \\
\text { treating DH. }\end{array}$ & 4weeks & $\begin{array}{l}\text { Tooth sensitivity score (TSS) measured on a } \\
0 \text {-10 visual analogue scale (VAS) after tactile } \\
\text { (probe) or thermal/evaporative (blast of air) } \\
\text { stimuli. For both stimuli, mean TSS was sig- } \\
\text { nificantly decreased in the VXT and Gluma } \\
\text { groups at all time points compared with } \\
\text { baseline. Regarding comparisons of TSS be- } \\
\text { tween treatment groups, the VXT group had } \\
\text { significantly lower mean TSS compared with } \\
\text { the Gluma group and placebo control group } \\
\text { at all time points after treatment regardless } \\
\text { of stimuli. Group Effect, Time Effect, and } \\
\text { Group x Time Effect were all significantly } \\
\text { different. }\end{array}$ \\
\hline 15 & $\begin{array}{l}\text { França IL, et } \\
\text { al. } 2015 \text { Brazil }\end{array}$ & $\begin{array}{l}\text { Randomized, } \\
\text { double blind } \\
\text { clinical trial }\end{array}$ & $\begin{array}{l}\mathrm{N}: 50 \text { patients } \\
\mathrm{G} 1: \text { product con- } \\
\text { taining } 8 \% \text { arginine } \\
\text { and calcium carbon- } \\
\text { ate (Test) } \\
\text { G2 : combination } \\
\text { of a conventional } \\
\text { prophylactic paste } \\
\text { and a potassium } \\
\text { nitrate dentifrice } \\
\text { (Control) }\end{array}$ & $\begin{array}{l}\text { To determine the efficacy } \\
\text { in reducing DH }\end{array}$ & 8 weeks & $\begin{array}{l}\text { The reductions in DH after 2, } 4 \text { and } 8 \text { weeks } \\
\text { were significant for both groups, however, } \\
\text { when considering Schiff scale, the Test treat- } \\
\text { ment provided greater DHS reduction after } \\
2 \text { weeks and } 4 \text { weeks, while after } 8 \text { weeks } \\
\text { there was no significant difference between } \\
\text { groups. }\end{array}$ \\
\hline 16 & $\begin{array}{l}\text { Antoniazzi } \\
\text { RP, et al. 2014, } \\
\text { Brazil }\end{array}$ & $\begin{array}{l}\text { Randomized, } \\
\text { double blind } \\
\text { clinical trial }\end{array}$ & $\begin{array}{l}\mathrm{N}: 107 \text { participants } \\
\text { with } 3 \text {-arm parallel } \\
\text { placebo gel, test gel } \\
\text { (5\% sodium fluoride, } \\
5 \% \text { potassium oxa- } \\
\text { late, } 10 \% \text { strontium } \\
\text { chloride) and } 2 \% \\
\text { sodium fluoride gel. }\end{array}$ & $\begin{array}{l}\text { To evaluate the effective- } \\
\text { ness of a desensitizing gel } \\
\text { for topical and } \\
\text { home use for the treatment } \\
\text { of DH }\end{array}$ & 1 month & $\begin{array}{l}\text { The greatest reductions in DH were } \\
\text { observed for the TG, with significant dif- } \\
\text { ferences for FG in the thermal and osmotic } \\
\text { stimuli. Considering the percentage of } \\
\text { participants with moderate/severe pain at } \\
30 \text { days, the TG demonstrated the lowest } \\
\text { percentages, with significant differences } \\
\text { in comparison with the other groups in } \\
\text { thermal and osmotic stimuli. }\end{array}$ \\
\hline 17 & $\begin{array}{l}\text { Ko Y, et al. } \\
2014 \text {, } \\
\text { Korea }\end{array}$ & $\begin{array}{l}\text { Randomized, } \\
\text { double blind } \\
\text { clinical trial }\end{array}$ & $\begin{array}{l}\mathrm{N}=96 \text { individuals } \\
\text { G1 test }: 48 \text { (laser) } \\
\text { G2 control: } 48 \text { (LED) }\end{array}$ & $\begin{array}{l}\text { To test the efficacy and the } \\
\text { safety of a low-level laser } \\
\text { emitting toothbrush on } \\
\text { management of DH. }\end{array}$ & 1 month & $\begin{array}{l}\text { Results demonstrated that the use of both } \\
\text { control and test toothbrushes resulted in } \\
\text { decreased discomfort after } 4 \text { weeks. This } \\
\text { decrease was significantly greater in the test } \\
\text { group. There were no significant adverse } \\
\text { events or side effects. It was concluded } \\
\text { that the use of the low-level laser emitting } \\
\text { toothbrush is a safe and effective treatment } \\
\text { option for the management of DH. }\end{array}$ \\
\hline
\end{tabular}

Table 3: Extraction of the data 
Among the 17 articles included in this systematic review, the following five $[9,11,12,14,15]$ were studies that assessed the clinical efficacy of various toothpastes for DH. Two articles were based on comparisons between lasers and sealers for the treatment of DH, and one article was in regard to a sealer and a glass ionomer cement [7,10,21]. Another was based on a comparison of a laser and a fluoride-containing mouthwash for the treatment of DH [19]. Four articles were devoted to assessment of the clinical efficacy of lasers for the treatment of $\mathrm{DH}[16,17,18,20]$. One article was an assessment of the effect of an ozone producing device on DH [8]. Lastly, three articles were in regard to the clinical efficacy of Pro-arginine mouthwashes and toothpastes on DH [6,13,22].

As for fluorinated coatings ( NaF) compared to GaAlAs, the outcomes of a clinical trial have shown that effects of NaF treatments are relative short in relation to irradiation by GaAlAs lasers [7].

As for lasers, at the clinical level all laser treatments that were assessed were able to reduce pain thresholds at one month of followup. All of the teeth retained their pulpal vitality. Er, Cr:YSGG at a power of $0.25 \mathrm{~W}$ exhibited the best performances in clinical evaluations [8].

Iontophoresis with $2 \% \mathrm{NaF}$ and the application of HEMA-G adhesive were seen to be equally effective with DH for all of the different stimuli at various time intervals. Topical application of $2 \%$ sodium fluoride with iontophoresis did not provide an immediate effect, but it did result in moderate relief of DH after 15 days [9].

A study of desensitizing gels comparing Oxa-Gel and Sensi Kill has shown that all of the formulations brought about significant reduction of $\mathrm{DH}$ by the second or third application (i.e. prior to the final treatment) [16].

\section{Discussion}

The effect of Iontophoresis with $2 \% \mathrm{NaF}$ and the application of HEMA-G adhesive dissipated steadily, such that it did not present a reliable long-term medication [9]. Sodium fluoride blocks the dentinal tubules as a result of precipitation of calcium fluoride crystals. Topical application is sometimes transitory and incomplete. Consequently, iontophoresis is seen as a way to transport the fluoride ions into the dentinal tubules.

Burke and Malik have suggested sealing the tubules or impregnating them with adhesive resin or an adhesive substance [23]. In this regard, glutaraldehyde is considered to be suitable, as it is a biological fixative that tends to denature proteins in the dentinal fluid, thereby sealing the dentinal tubules. HEMA-G resin, which is water-soluble, can promote deep penetration of the glutaraldehyde into the tubules, thereby leading to the formation of an intrinsic peripheral barrier comprised of multiple thin partitions within the lumen [24]. The results also revealed a decrease in the efficacy for all of the stimuli after three months, and this can be attributed to a relatively rapid loss of the $\mathrm{CaF}_{2}$ occlusion layer as it is diluted by saliva. This may explain why topical application of $\mathrm{NaF}$ is limited in terms of its long-term efficacy in regard to sensitivity. As for calcium sodium phosphosilicate (CSPS; Nova Min), a single professionally-applied application of prophylactic paste containing this active constituent allowed for a significant reduction of $\mathrm{DH}$ both straightaway and 28 days after scaling and root planning. This effect was independent of the presence of fluoride in the prophylactic paste. Mechanical occlusion of the dentinal tubules, or regulation of the nerve response, have been reported to be effective ways to reduce $\mathrm{DH}[25]$.

The mode of action of CSPS has been studied in vitro, and it involves formation of a layer of chemically and mechanically stable apatite, such as calcium hydroxide carbonate [26]. The initial activity of CSPS particles in vitro has been shown to involve formation of a negative charge on the surface of the exposed dentin, thus allowing formation of covalent bonds between the CSPS and chemical moieties of the dentin type 1 collagen fibers [27]. Localized precipitation of apatite has been attributed to the immediate release of sodium ions when CSPS come in contact with water or saliva. This induces a local increase in the $\mathrm{pH}$ which then promotes the release of calcium and phosphate ions [16]. The results of de systematic review conducted by Zhu showed that the majority of studies found that calcium sodium phosphosilicate was more effective than the negative control at alleviating $\mathrm{DH}$ [28].

Comparison of the desensitizing efficacy of a new toothpaste containing carbonate and hydroxyapatite nanocrystals, as well as a sodium fluoride and potassium nitrate toothpaste has shown that these two toothpastes are effective [12]. These findings are in keeping with the meta-analysis by Poulsen, et al. in 2001, which revealed a statistically significant effect of potassium nitrate $\left(\mathrm{KNO}_{3}\right)$ toothpaste after 6 to 8 weeks of follow-up [29].

Treatment of $\mathrm{DH}$ is based on the notion of reducing fluid movement inside the dentin tubules by restriction or occlusion of the tubules [30]. In light of this notion, the advent of dental lasers has led to an alternative treatment option [31]. It has been shown that hypersensitive teeth have tubular diameters that are significantly greater than those for teeth that are not sensitive. Thus, it would appear that treatment should focus on depolarization of nerve fibers, although reduction of the diameter of the dentin tubules is a prior requirement for effective desensitization [32]. The aim of using high-intensity lasers is to seal the dentin tubules or to alter the content of the tubules by coagulation, protein precipitation, or the formation of insoluble calcium complexes [31]. Prior clinical studies have shown that Nd:YAG lasers effectively reduce DH brought on by cold air stimulation [33].

A comparison of erbium, chromium-doped yttrium, scandium, gallium and garnet (Er, Cr: YSGG) and gallium-aluminumarsenide lasers has revealed an immediate desensitizing effect following treatment, and this effect was maintained throughout the study period $(\mathrm{p}<0.05)$ [34]. No significant difference was seen between Er, Cr: YSGG and GaAlAs groups in the course of the 
follow-up examinations ( $\mathrm{p}>0.05)$. These findings are in keeping with the meta-analysis by Sgolastra F, et al. which revealed Er:YAG, Nd:YAG, and GaAlAs lasers appear to be efficacious in reducing DH [35]. However, given the high heterogeneity of the included studies, future randomized controlled clinical trials are needed to confirm these results. Blatz MB in his systematic review concluded that the results obtained from the 8 studies included in this systematic review were conflicting but indicated a slight clinical advantage of laser therapy over topical medicaments in the treatment of dentin hypersensitivity [36]. It was further concluded that application of lasers under controlled parameters for this indication may not lead to adverse effects.

Prior studies have, however, indicated that the effects of numerous topical desensitizing agents, toothpastes, and products containing aluminum and ferric potassium oxalates are not permanent as they do not adhere to the surface of the dentin [10].

Stimulation of odontoblasts, production of reactive dentin, and occlusion of dentin tubules induced by a diode laser can underlie the prolonged suppression of DH pain [37]. Light from an Er, Cr:YSGG laser is absorbed more strongly by OH ions of water molecules if the laser can cause an increase in the surface temperature, and this can hence alter the mineral content of the enamel and the dentin [38]. Freitas, et al. recently indicated that low-power laser irradiation from an Er, Cr:YSGG laser at 0.25W or 0.5W allows the surface to become more resistant to acid consequent to changes in the structure of the enamel due to the chemical entities that are produced [13]. These authors hence speculated that Er, Cr:YSGG lasers can reduce DH in the long run due to the prevention of caries and due to effects on the decrease in solubility of the hard dental tissues. The present study has shown that positive outcomes with radiation from these two types of lasers were maintained for three months without any secondary effects.

Comparison of neodymium-doped yttrium aluminum garnet (Nd: YAG) and fluorinated coatings has shown that Nd: YAG lasers are appropriate devices for achieving immediate success with reducing DH, and they result in a higher degree of patient satisfaction and a shorter treatment time [19]. They represent an effective and fast treatment option for DH.

As for fluorinated coatings ( $\mathrm{NaF}$ ) compared to GaAlAs, the finding may be attributed to the mode of action of NaF, which is based on mechanical occlusion without adhesion [7,39]. These lasers provide an immediate analgesic effect by targeting of nerve transmission [40]. Based on physiological experiments, the immediate effect of GaAlAs lasers is caused by blockage of the depolarization of afferent C fibers [41]. The conclusion of the systematic review conducted by He was that there is no strong evidence that laser therapy decreases dentine hypersensitivity [42]. Given the cost, questionable efficacy and unknown safety of this treatment, and the availability of other treatments, dentists should be cautious when using laser therapy for treatment of dentine hypersensitivity patients. The evidence base for recommending this treatment is weak and further clinical trials with adequate sample size and design are necessary to guide clinical practice.

A comparison of an arginine-based mouthwash ( $0.8 \%$ arginine, PVM/MA copolymer, pyrophosphates, and $0.05 \%$ sodium fluoride) versus a placebo mouthwash without alcohol and without other components has shown that the arginine mouthwash provided a significant reduction in $\mathrm{DH}$ after eight weeks of use relative to a negative control mouthwash [13]. Other studies have shown that a toothpaste containing $8 \%$ arginine, calcium carbonate, and 1,450 ppm of sodium monofluorophosphate provided a greater efficacy in terms of reducing DH, relative to a desensitizing toothpaste containing $2 \%$ potassium ions [43,44]. Furthermore, direct topical self-application of the product at the site in question provided immediate relief of the dentin sensitivity [45].

As an alternative, or to complement desensitizing toothpaste, a new mouthwash formulation with $0.8 \%$ arginine and $0.05 \%$ sodium fluoride has been developed that, in conjunction with a copolymer of PVM / MA triggers occlusion of the tubules. Another study that focused on comparison of a toothpaste and a mouthwash based on arginine and potassium has revealed that the arginine-based treatment was more effective than the one with potassium [13]. Two other studies have shown a decrease in DH using arginine compared to potassium $[25,43]$. These findings are in keeping with a systematic review and meta-analysis by Bae $\mathrm{JH}$ which revealed that there is sufficient evidence to support the use of potassium-, stannous fluoride-, potassium and stannous fluoride-, calcium sodium phosphosilicate-, and arginine-containing desensitizing toothpastes for dentin hypersensitivity, but not the use of strontium-containing desensitizing toothpaste [46].

\section{Conclusions}

This systematic review has shown that the majority of options for active treatment, including physical occlusion, chemical occlusion, laser-based therapy, and combined treatments have better outcomes than placebos.

Comparisons between the various therapeutic options did not reveal any significant short-term differences, although the laserbased treatments proved to be much more effective in the long run. The same can be said for cyanoacrylate, which was found to be as effective as low-intensity laser treatment for reducing dentin hypersensitivity. Further, it is a more readily accessible and less costly procedure that is entirely safe for use in treating dentin hypersensitivity.

However, given the high heterogeneity of the included studies and the five studies with an elevated risk of bias, future randomized controlled clinical trials are needed to confirm these results.

\section{References}

1. Holland GR, Narhi MN, Addy M, Gangarosa L, Orchardson R (1997) Guidelines for the design and conduct of clinical trials on dentine Hypersensitivity. J Clin Periodontol 24: 808-13. 
2. Dababneh RH, Khouri AT, Addy M (1999) Dentin hypersensitivity-an enigma? A review of terminology, epidemiology, mechanisms, aetiolog and management. Br Dent J 187: 606-11.

3. Dowell P, Addy M (1983) Dentine hypersensitivity a review. Aetiology, symptoms and theories of pain production. J Clin Period 10: 341-50.

4. Lin PY, Cheng YW, Chu CY, Chien KL, Lin CP, et al. (2013) In-office treatment for dentin hypersensitivity: a systematic review and network meta-analysis. J Clin Periodontol 40: 53-64.

5. Turner L, Shamseer L, Altman DG, Weeks L, Peters J, et al. (2012) Consolidated standards of reporting trials (CONSORT) and the completeness of reporting of randomised controlled trials (RCTs) published in medical journals. Cochrane Database Syst Rev 11: MR000030.

6. Elias Boneta AR, Ramirez K, Naboa J, Mateo LR, Stewart, B, et al. (2013) Efficacy in reducing dentine hypersensitivity of a regimen using a toothpaste containing $8 \%$ arginine and calcium carbonate, a mouthwash containing $0.8 \%$ arginine, pyrophosphate and PVM/MA copolymer and a toothbrush compared to potassium and negative control regimens: an eight-week randomized clinical trial. J Dent 41: 42-9.

7. Yilmaz HG, Kurtulmus-Yilmaz S, Cengiz E (2011) Long-term effect of diode laser irradiation compared to sodium fluoride varnish in the treatment of dentine hypersensitivity in periodontal maintenance patients: a randomized controlled clinical study. Photomed Laser Surg 29: 721-5.

8. Azarpazhooh A, Limeback H, Lawrence HP, Fillery ED (2009) Evaluating the effect of an ozone delivery system on the reversal of dentin hypersensitivity: a randomized, double-blinded clinical trial. J Endod 35: 1-9.

9. Brahmbhatt N, Bhavsar N, Sahayata V, Acharya A, Kshatriya P (2012) A double blind controlled trial comparing three treatment modalities for dentin hypersensitivity. Med Oral Patol Oral Cir Bucal 17: 483-90.

10. Flecha OD, Azevedo CG, Matos FR, Vieira-Barbosa NM, Ramos-Jorge ML, et al. (2013) Cyanoacrylate versus laser in the treatment of dentin hypersensitivity: a controlled, randomized, double-masked and non-inferiority clinical trial. J Periodontol 84: 287-94.

11. Neuhaus KW, Milleman JL, Milleman KR, Mongiello KA, Simonton TC, et al. (2013) Effectiveness of a calcium sodium phosphosilicate-containing prophylaxis paste in reducing dentine hypersensitivity immediately and 4 weeks after a single application: a double-blind randomized controlled trial. J Clin Periodontol 40: 349-57.

12. Orsini G, Procaccini M, Manzoli L, Giuliodori F, Lorenzini A, et al. (2010) A double-blind randomized-controlled trial comparing the desensitizing efficacy of a new dentifrice containing carbonate/hydroxyapatite nanocrystals and a sodium fluoride/potassium nitrate dentifrice. J Clin Periodontol 37: 510-7.

13. Hu D, Stewart B, Mello S, Arvanitidou L, Panagakos F, et al. (2013) Efficacy of a mouthwash containing $0.8 \%$ arginine, PVM/MA copolymer, pyrophosphates, and $0.05 \%$ sodium fluoride compared to a negative control mouthwash on dentin hypersensitivity reduction. A randomized clinical trial. J Dent 41: 26-33.

14. He T, Barker ML, Biesbrock AR, Miner M, Qaqish J, et al. (2014) A clinical study to assess the effect of a stabilized stannous fluoride dentifrice on hypersensitivity relative to a marketed sodium fluoride/triclosan control. J Clin Dent 25: 13-8.

15. Antoniazzi RP, Machado ME, Grellmann AP, Santos RC, Zanatta FB (2014) Effectiveness of a desensitizing agent for topical and home use for dentin hypersensitivity: a randomized clinical trial. Am J Dent 27: 251-7.

16. Assis JS, Rodrigues LK, Fonteles CS, Colares RC, Souza AM, et al. (2011) Dentin hypersensitivity after treatment with desensitizing agents: a randomized, double-blind, split-mouth clinical trial. Braz Dent J 22: 157-61.

17. Ko Y, Park J, Kim C, Park J, Baek SH, et al. (2014) Treatment of dentin hypersensitivity with a low-level laser-emitting toothbrush: double-blind randomized clinical trial of efficacy and safety. J Oral Rehabil 41:23-31.

18. Aranha AC, Eduardo Cde P (2012) Effects of Er:YAG and Er,Cr:YSGG lasers on dentine hypersensitivity. Short-term clinical evaluation. Lasers Med Sci 27: 813-8.

19. Kara C, Orbak R (2009) Comparative evaluation of Nd:YAG laser and fluoride varnish for the treatment of dentinal hypersensitivity. J Endod 35: 971-4.

20. Yilmaz HG, Kurtulmus-Yilmaz S, Cengiz E, Bayindir H, Aykac Y (2011) Clinical evaluation of Er,Cr:YSGG and GaAlAs laser therapy for treating dentine hypersensitivity: A randomized controlled clinical trial. J.Dent 39: 249-54.

21. Ding YJ, Yao H, Wang GH, Song H (2014) A randomized double-blind placebo controlled study of the efficacy of Clinpro XT varnish and Gluma dentin desensitizer on dentin hypersensitivity. Am J Dent 27: 79-83.

22. França IL, Sallum EA, Do Vale HF, Casati MZ, Sallum AW, et al. (2015) Efficacy of a combined in-office/home-use desensitizing system containing $8 \%$ arginine and calcium carbonate in reducing dentin hypersensitivity: an 8-week randomized clinical study. Am J Dent 28: 45-50.

23. Burke FJ, Malik R, McHugh S, Crisp RJ, Lamb JJ (2000) Treatment of dentinal hypersensitivity using a dentine bonding system. Int Dent J 50: $283-8$.

24. Schupbach P, Lutz F, Finger WJ (1997) Closing of dentinal tubules by Gluma desensitizer. Eur J Oral Sci 105:414-21.

25. Wara-aswapati N, Krongnawakul D, Jiraviboon D, Adulyanon S, Karimbux N, et al. (2005) The effect of a new toothpaste containing potassium nitrate and triclosan on gingival health, plaque formation and dentine hypersensitivity. J Clin Periodontol 32: 53-8.

26. Litkowski L, Hack, GD, Sheaffer, HB, Greenspan, DC (1997) Occlusion of dentine tubules by 4555 bioglass. In: Sedel L, Rey C (eds.) Bioceramics 10, Proceedings of the 10th International Symposium on Ceramics in Medicine, Paris, France.

27. Oréfice R, Hench L, Brennan A (2009) Evaluation of the interactions between collagen and the surface of a bioactive glass during in vitro test. J Biomed Mater Res A 90: 114-20.

28. Zhu M, Li J, Chen B, Mei L, Yao L, et al. (2015) The Effect of Calcium Sodium Phosphosilicate on Dentin Hypersensitivity: A Systematic Review and MetaAnalysis. PLoS One 6:1-15.

29. Poulsen S, Errboe M, Hovgaard O, Worthington HW (2001) Potassium nitrate toothpaste for dentine hypersensitivity. Cochrane Database Syst Rev 2: CD001476.

30. Addy M, Smith SR (2010) Dentine hypersensitivity: an overview on which to base tubule occlusion as a management concept. J Clin Dent 21: 25-30.

31. Kimura Y, Wilder-Smith P, Yonaga K, Matsumoto K (2000) Treatment of dentine hypersensitivity by lasers: a review. J Clin. Periodontol 27: 715-21.

32. Rees JS, Jin LJ, Lam S, Kudanowska I, Vowles R (2003) The prevalence of dentine hypersensitivity in a hospital clinic population in Hong Kong. J Dent 31: $453-61$.

33. Ciaramicoli MT, Carvalho RC, Eduardo CP (2003) Treatment of cervical dentin hypersensitivity using neodymium:Yttrium-aluminum-garnet laser. Clinical evaluation. Lasers Surg Med 33: 358-62.

34. Lan WH, Lee BS, Liu HC, Lin CP (2004) Morphologic study of Nd:YAG laser usag in treatment of dentinal hypersensitivity. J Endod 30: 131-4.

35. Sgolastra F, Petrucci A, Severino M, Gatto R, Monaco A (2013) Lasers for the treatment of dentin hypersensitivity: a meta-analysis. J Dent Res $92: 492-9$. 
36. Blatz MB (2012) Laser therapy may be better than topical desensitizing agents for treating dentin hypersensitivity. J Evid Based Dent Pract 12: 69-70.

37. Pesevska S, Nakova M, Ivanovski K, Angelov N, Kesic L, et al. (2010) Dentinal hypersensitivity following scaling and root planing: comparison of low-level laser and topical fluoride treatment. Lasers Med Sci 25: 647-50.

38. Hansen EK (1992) Dentin hypersensitivity treated with a fluoride-containing varnish or a light-cured glass-ionomer liner. Scand J Dent Res 100: 305-9.

39. Ganss C, Schlueter N, Klimek J (2007) Retention of KOH-soluble fluoride on enamel and dentine under erosive conditions--A comparison of in vitro and in situ results. Arch Oral Biol 52: 9-14.

40. Jacobson PL, Bruce G (2001) Clinical dentin hypersensitivity understanding the causes and prescribing a treatment. J Contemp Dent Pract 2: 1-8.

41. Ladalardo TC, Pinheiro A, Campos RA, Brugnera Júnior A, Zanin F, et al. (2004) Laser therapy in the treatment of dentine hypersensitivity. Braz Dent J 15: 144-50.

42. He S, Wang Y, Li X, Hu D (2011) Effectiveness of laser therapy and topical desensitising agents in treating dentine hypersensitivity: a systematic review. J Oral Rehabil 38: 348-58

43. Ayad F, Berta R, De Vizio W, McCool J, Petrone ME, et al. (1994) Comparative efficacy of two dentifrices containing 5\% potassium nitrate on dentinal sensitivity: a twelve-week clinical study. J Clin Dent 5: 97-101.

44. Docimo R, Montesani L, Maturo P, Costacurta M, Bartolino M,et al. (2009) Comparing the efficacy in reducing dentin hypersensitivity of a new toothpaste containing $8.0 \%$ arginine, calcium carbonate, and $1450 \mathrm{ppm}$ fluoride to a benchmark commercial desensitizing toothpaste containing $2 \%$ potassium ion: an eightweek clinical study in Rome, Italy. J Clin Dent 20: 137-43.

45. Ayad F, Ayad N, Zhang YP, DeVizio W, Cummins D, et al. (2009) Comparing the efficacy in reducing dentin hypersensitivity of new toothpaste containing $8.0 \%$ arginine, calcium carbonate, and $1450 \mathrm{ppm}$ fluoride to a commercial sensitive toothpaste containing $2 \%$ potassium ion: an eight-week clinical study on Canadian adults. J Clin Dent 20: 10-6.

46. Bae JH, Kim YK, Myung SK (2015) Desensitizing toothpaste versus placebo for dentin hypersensitivity: a systematic review and meta-analysis. J Clin Periodontol 42: 131-41. 